DOI: $10.1515 /$ pof-2017-0027

VOLUME 9, ISSUE 3, 2017

ISSN: $2036-5438$

\title{
An Opportunity for Reflection -
}

\section{A Special Issue on "The Constitution of Canada: History, Evolution, Influence and Reform"}

by

Giuseppe Martinico, Richard Albert, Antonia Baraggia and Cristina Fasone* 


\section{Abstract}

Canada is and will for the foreseeable future be a peaceful and prosperous liberal democracy whose Constitution Act, 1867, now 150 years old as of 2017, has become a model for the modern world. The Constitution of Canada has exerted considerable influence on other countries, particularly since the coming into force of its Constitution Act, 1982, which included the celebrated Canadian Charter of Rights and Freedoms. Just as Canada drew from foreign and international experiences in drafting its Charter, the world has learned a great deal from Canada, not only as to rights protections but also as to the separation of powers, the judicial function, and the structure of government.

In light of these impressive achievements, an international symposium on the Canadian Constitution was held in Pisa at the Scuola Sant'Anna under the auspices of the Sant'Anna Legal Studies project and with the support of the DIRPOLIS (Law, Politics and Development) Institute at the Scuola Sant'Anna, the Canadian Embassy in Italy, and the International Association of Constitutional Law. This special issue collects some of the papers presented on that occasion.

Key-words

Canada, migration of constitutional ideas, comparative constitutional law, patriation, Canadian Charter of Rights and Freedoms 


\section{Why a Special Issue on Canada?}

In Constitutional Odyssey: Can Canadians Become a Sovereign People? $?^{\mathrm{I}}$, Peter Russell (1992) describes Canada's long march to the "patriation" "II of the constitution, the dramatic failure of the Meech Lake and Charlottetown Accords, and the difficulty of reconciling Quebec with the rest of the country since the sovereignty-association referendum in 1980. For Russell, Canada's turbulent "constitutional odyssey" derives from its Burkean, not Lockean, culture of constitutionalism. With some noteworthy exceptions including patriation itself, Canadian political actors, Russell explains, have favoured incremental adjustments to their constitutional arrangements rather than a Lockean democratic moment in which a nation is forged and a people is created. In Russell's analysis, Canada is a nation of nations, home to dissimilar peoples for whom the idea of an American-style sense of collective peoplehood is perhaps neither a priority nor even a possibility. And yet Canada remains today and for the foreseeable future a peaceful and prosperous liberal democracy whose Constitution Act, 1867, now 150 years old as of 2017, has become a model for the modern world.

The Constitution of Canada has exerted considerable influence on other countries, particularly since the coming into force of its Constitution Act, 1982, which included the celebrated Canadian Charter of Rights and Freedoms. Just as Canada drew from foreign and international experiences in drafting its Charter, the world has learned a great deal from Canada, not only as to rights protections but also as to the separation of powers, the judicial function, and the structure of government. Canada, it turns out, exports much more than only hockey players and peacekeepers.

In this spirit, we organized an international symposium on the Canadian Constitution. We held the program in Pisa at the Scuola Sant'Anna under the auspices of the Sant'Anna Legal Studies project and with the support of the DIRPOLIS (Law, Politics and Development) Institute at the Scuola Sant'Anna, the Canadian Embassy in Italy, and the International Association of Constitutional Law.

The symposium offered a special opportunity for scholars from all around the world to gather to mark the Sesquicentennial of the Canadian Constitution. We invited participants 
from all perspectives, including both critical and praiseworthy, to present papers on a wideranging theme: "The Constitution of Canada: History, Evolution, Influence and Reform." This special issue collects some of the papers presented on that occasion. It is true that important volumes have already been published on this anniversary. ${ }^{\text {III }}$ But there nonetheless remains much to say about a Constitution that has had such a profound impact beyond its borders, particularly here in Europe, where many of the contributors to this special issue are based. We are especially pleased to have curated a genuinely comparative special issue of reflections on the Constitution of Canada.

\section{In this Issue}

The articles collected in this Special Issue fall under three themes, each reflecting peculiar characteristics of Canadian constitutional law in a comparative perspective. The first is Federalism, which James Gardner, Peter Price, and Davide Strazzari investigate from different perspectives and each with a different subject-matter focus, namely the structure of governmental power, the dynamic relationship between federal and provincial constitutions, and the evolution of the federal system on public policy, respectively.

James Gardner's article on "Canadian Federalism in Design and Practice: The Mechanics of a Permanently Provisional Constitution" deals with the federal structure of the Canadian Constitution. It focuses on the existing gap between constitutional design and practice in the case of Canada and highlights the strategies and tactics put in place by provinces to assert their authority to and against the federal government. The article shows that, by using tools like constitutional conventions and executive federalism, provinces have in fact created for themselves considerable leeway to get much of what they have wanted from the central government. The (unintended) consequence, however, has been to keep the Constitution in moving to and from ever-changing equilibria between the central and subnational governments.

In his article on "Provincializing Constitutions: History, Narrative, and the Disappearance of Canada's Provincial Constitutions", Peter Price argues that the dominant narrative in Canadian constitutional discourse since 1867 has caused us to overlook the importance of provincial Constitutions. The result has been to minimize pre-Confederation Canadian history and, thus, the significance of the many constitutional communities and 
identities shaping the original "dualist" view of the Constitution. Price traces this phenomenon to the increased weight assigned to written constitutionalism in the postCharter era- a trend that combines with the lack of codified provincial constitutions in Canada to make provincial constitutions much less important than they really are and ought to be.

Davide Strazzari's contribution on "Immigration and Federalism in Canada: beyond Quebec Exceptionalism?” aims to shed light on the balance of powers between the central government and the provinces in the specific and controversial case of migration policy. In his article, Strazzari demonstrates that since the 1991 intergovernmental agreement between the federal government and the government of Quebec on the issue (which allocated crucial powers to Quebec in matters of selection and integration of migrants), the federation has conferred more authority over immigration also to other provinces and territories, causing a shift from de jure to de facto asymmetry among provincial powers. However, as Strazzari clearly points out, while Quebec's autonomy in migration may be constrained only by an Act of the Parliament, the delegation of powers over migration to the other provinces and territories is based on administrative agreements that can be unilaterally revoked by the federal government—as happened not too long ago in 2012.

The second group of articles in this Special Issue contributes to the literature on the "migration of constitutional ideas" has travelled across borders. As one of the world's most influential ${ }^{\mathrm{V}}$, the Canadian Constitution presents many avenues for research into how its doctrines, theories and innovations have been transplanted or adapted abroad. Leonardo Pierdominici's article on "The Canadian living tree doctrine as a comparative model of evolutionary constitutional interpretation" analyses the influence of the "living tree" doctrine of the Supreme Court of Canada on courts that are traditionally engaged in transnational judicial dialogue and courts that are newcomers to this practice.

In "Constitutional Judges and Secession. Lessons from Canada ... twenty years after" Irene Spigno examines how the referendum has been used to address secessionist claims outside Canada in particular Italy and Spain. She draws in her article on the advisory opinion of the Supreme Court of Canada on Quebec secession. She inquires whether the principles articulated in that advisory opinion have been influential in the case law of the 
Italian and Spanish Constitutional Courts, both of which have faced similar questions about secession.

Similarly, the article by Francisco Javier Romero Caro on "The Spanish vision of Canada's Clarity Act: From Idealization to Myth" begins with the advisory opinion on Quebec secession. He focuses on its legislative follow-up in Parliament, the Clarity Act, to explore the reasons for and the pitfalls of the "deification of this statute in Spain". He argues in particular that the Clarity Act has been misinterpreted in Spain, with serious consequences for the treatment of secessionist claims in the Basque country and in Catalonia.

The third group of articles in this Special Issue focuses on the enforcement of the equality principle in Canada, in particular on the protection of gender equality and women's rights. Charlotte Helen Skeet's contribution on "Franchises Lost and Gained: PostColoniality and the Development of Women's Rights in Canada" challenges the traditional understanding of the "continuous evolution" and strengthening of women's political rights with reference to the pre-confederation history of suffrage in Canada as a case study. Her historical and legal analysis of the suffrage movements in the country show why the franchise was exercised more widely in Lower Canada and it also urges the recognition of the contributions to Indigenous peoples to the history of women's rights in Canada. Valentina Rita Scotti's article on 'Women's Rights and Minorities' Rights in Canada: The Challenges of Intersectionality in Supreme Court Jurisprudence" tackles the issue of gender equality and minority rights with a careful study of the case law of the Canadian Supreme Court. After framing the debate on intersectionality in the Canadian context and after reviewing some of the main Supreme Court judgments on gender equality, Scotti then interrogates why and how intersectionality represents for Indigenous and Muslim women a source of double discrimination.

What follows, then, is a fascinating, provocative and timely set of articles that raise important questions about, raise useful critiques of and where appropriate bring a certain amount of praise to the Constitution Act, 1867 as it marks its Sesquicentennial. We can only hope that the Canadian Constitution will continue to be a source of learning and inspiration in the years ahead. 


\footnotetext{
* Giuseppe Martinico is Associate Professor of Comparative Public Law at Scuola Superiore Sant'Anna in Pisa. Richard Albert is tenured Professor of Constitutional Law at Boston College Law School. Antonia Baraggia is Postdoctoral Fellow in Constitutional Law at the University of Milan. Cristina Fasone is Assistant Professor of Comparative Public Law at LUISS Guido Carli in Rome.

I Russell 1992.

II “'The word 'patriation', a genuine Canadian invention, refers to Canada's final 'bringing home' of its constitution from Westminster, with full patriotic fanfare, on 17 April 1982. Although Canada enjoyed sovereignty since at least 1931, it nonetheless continued to depend on requests to the United Kingdom Parliament for making amendments to its constitution. The reason for this anomaly was clear: Canadian governments had proved unable to agree on an internal amending procedure by which legal changes to the constitution could be made at home without having recourse to Britain" (Milne 2004).

III See, for example, Albert and Cameron (eds) 2017; Oliver, Macklem and Des Rosiers (eds) 2017.
}

\section{References}

- $\quad$ Albert Richard and Cameron David R. (eds), 2017, Cambridge University Press, Cambridge.

- Choudhry Sujit (ed), 2009, The Migration of Constitutional Ideas, Cambridge University Press, Cambridge.

- $\quad$ Fossum John Erik, 2004, 'Why Compare Canada and the European Union - and How?', in Crowley Patrick M. (ed), Crossing the Atlantic: Comparing the European Union and Canada, Ashgate, London, 11-34.

- Fossum John Erik, Poirier Johanne and Magnette Paul (eds), 2009, The Ties that Bind: Accommodating Diversity in Canada and the European Union, Peter Lang, Brussels.

- $\quad$ Hirschl Ran, 'Going Global? Canada As Importer and Exporter of Constitutional Thought', in Albert Richard and Cameron David R. (eds), Canada In The World: Comparative Perspectives on The Canadian Constitution, Cambridge University Press, Cambridge, 305-324.

- $\quad$ Kay Richard S., 2005, 'Book Review Essay: Canada’s Constitutional Cul De Sac', American Review of Canadian Studies, XXXV(4): 705-714.

- $\quad$ Law David S. \& Versteeg Mila, 2012, 'The Declining Influence of the United States Constitution', New York University Law Review, LXXXVII(3): 762-858.

- Milne David, 2004, entry 'Patriation of the Constitution - Canada, Constitutional, Quebec, Amendments, Consent, and link http://www.oxfordreference.com/view/10.1093/oi/authority.20110803100310612.

- Oliver Peter, Macklem Patrick and Des Rosiers Nathalie (eds), 2017, The Oxford Handbook of the Canadian Constitution, Oxford University Press, Oxford.

- $\quad$ Russell Peter H., 1992, Constitutional Odyssey: Can Canadians Become a Sovereign People?, University of Toronto Press, Toronto.

- $\quad$ Russell Peter H., 2017, Canada's Odyssey: A Country Based on Incomplete Conquests, University of Toronto Press, Toronto. 